\title{
Barregã e Manceba: Dois Estatutos Diferentes? As Cartas de Perdão na Chancelaria de D. João II
}

\author{
Márcia dos Santos Coutinho \\ marciakoutinho2016@gmail.com
}

\section{Resumo}

O presente artigo aborda a temática das barregãs e mancebas na Idade Média, procurando entender qual o seu estatuto na sociedade medieva, bem como as possíveis características que as distinguem. Com um foco legislativo, a análise resulta do estudo de Cartas de Perdão, outorgadas por D. João II, e das Ordenações Afonsinas. O recurso a estas fontes permite compreender se a barregania ou mancebia correspondem a estatutos diferentes, tanto na prática como na própria legislação, apesar da sua semelhança e pertença à realidade marginal da sexualidade. Será, ainda, realizada uma análise às penas inerentes, bem como ao papel da mulher na sociedade.

Palavras-chave: Família, Casamento, Marginalidade, Direito, Igreja, Mulher.

\begin{abstract}
This article discusses the theme of concubines and prostitutes in the Middle Ages, seeking to understand their status in the medieval society, as well as the possible characteristics that distinguish them. With a legislative focus, the present analysis results from the study of Pardon Letters, granted by D. João II and Ordenações Afonsinas, a legislative compilation of the XV century. The use of these sources makes it possible to understand whether concubinage or prostitution correspond to different statutes, both in practice and in legislation, despite their similarity and belonging to the marginal reality of sexuality. An analysis will also be made of the inherent penalties, as well as of the role of women in society.
\end{abstract}

Keywords: Family, Marriage, Marginality, Rights, Religion, Woman. 


\section{Introdução}

O mundo medieval faz parte do imaginário de todos nós - e a sexualidade dos homens e das mulheres que o habitaram representa uma das maiores incógnitas deste universo. Face às parcas fontes de informação, para a cronologia medieva, devido à perda de documentação ou à sua pouca produção, torna-se um desafio reconstruir a vida social e a interação entre os indivíduos. Neste sentido, a esfera individual das interações familiares, sociais, matrimoniais, sexuais e de relacionamentos interpessoais, é fonte de curiosidade e mistério.

$\mathrm{Na}$ construção da narrativa histórica, principalmente para o grande público, associou-se a Idade Média a um forte controlo do comportamento social por parte da Igreja, através dos seus preceitos morais e ideológicos. Todavia, este período corresponde a uma elevada coexistência de valores e práticas diferentes, face à vasta cronologia que o delimita, bem como às realidades que o influenciam. Os valores pagãos influenciam fortemente a sociedade, pois o discurso teológico 'castrador' só começa quando a Igreja se pretende sobrepor a outros poderes e inicia o seu processo de fortalecimento. Portanto, a valorização das suas ideologias e a sua adoção na vida quotidiana é completada na Idade Moderna, durante a qual o poderio do Papado é enorme e as ideologias e práticas que emana se transformam na regra a seguir. Com isto, reduzir o período medieval à prática religiosa e aos seus valores é extremamente redutor. Pois, apesar de existir um respeito pela religião cristã, há a coexistência de uma elevada tolerância para com a união livre entre homem e mulher, a liberdade de costumes e uma diversidade de comportamentos. É, portanto, uma sociedade cujos comportamentos são mais livres em comparação com a modernidade, período em que a implementação da Inquisição permite um maior controlo dos indivíduos e práticas.

Por tudo isto é essencial não tirar ilações de certos documentos legisladores ou clericais, pois nem sempre correspondem às práticas quotidianas nem são aplicados de forma uniforme. São, sim, reflexos dos costumes e valores que se procura instalar. Desta forma, existe um abismo entre as fontes, a legislação e as práticas quotidianas, visto que o facto de determinado comportamento sexual, por exemplo, ser condenado não significa que não fosse praticado. Afinal, as ações do foro privado, na casa dos indivíduos, não são do conhecimento dos historiadores, na medida em que não ficaram documentadas. A existência de uma regra não é, por si só, imperativa da sua execução.

Neste sentido, decidi abordar o tema da barregania, prática comum durante a Idade Média coexistente com o modelo de casamento que a Igreja tenta implementar na sequência da chamada "Reforma Gregoriana". Associei, depois à pesquisa a mancebia, pela sua proximidade 
conceitual e pela necessidade de compreender se estas duas realidades eram até certo ponto confundidas. Ambas consideradas pecado e crime, são condenadas pela legislação e parecem pertencer à marginalidade medieval. Sendo associadas à mulher, maioritariamente, tornam-se uma plataforma para a compreensão do seu papel e funções na sociedade medieva.

Dentro desta temática e recorrendo à Chancelaria de D. João II e às Ordenações Afonsinas, o estudo pretende responder às seguintes questões: De que forma a justiça régia atuava face a mancebas e a barregãs? Eram aplicadas multas? Quem cometia e estava mais associado a estes crimes? Afinal, existe uma confusão entre estes dois termos? Qual o seu processo evolutivo na legislação portuguesa?

A Chancelaria, composta por cartas régias, permite analisar a atuação do monarca em todo o espaço geográfico português. As cartas de perdão outorgadas pelo rei, são a base deste trabalho. A sua utilização por parte do monarca tinha como intuito controlar a criminalidade e a delinquência do reino. Através delas é possível em alguma medida reconstruir o quotidiano e as práticas correntes, bem como a marginalidade e o funcionamento da justiça.

Por sua vez, as Ordenações Afonsinas ${ }^{1}$ são a primeira compilação de leis e fontes jurídicas do Reino de Portugal $^{2}$, promulgadas no reinado de D. Afonso V. A sua publicação facilitou a atuação da justiça, que se tornou mais eficaz. A utilização desta fonte no presente trabalho é essencial, para que se compreenda a evolução da barregania e da mancebia na legislação.

Resta agora referir o método utilizado para a elaboração do presente estudo. Em primeiro lugar, partiu da escolha do tema das fontes em cima referidas. O estudo das Ordenações focou-se no Livro $\mathrm{V}$ na leitura dos títulos relacionados com esta prática, e a identificação das multas e procedimentos. Por sua vez, a análise da Chancelaria dividiu-se em dois momentos: a definição de duas palavras-chave e a sua busca, sendo elas barreg e mance, e, posteriormente, a sua análise. Não foi definida qualquer cronologia, de forma a recolher a maior quantidade de informação válida. Foram estudadas 237 cartas de perdão, 100 aludindo à barregania e 137 à mancebia. A leitura de documentação não foi proporcional, na medida em que os resultados referentes à barregania foram alcançados com a leitura de 16 livros, ao passo que na mancebia foram consultados três livros. ${ }^{3}$ A presente amostra é reduzida tendo em conta

\footnotetext{
${ }^{1}$ Ordenações Afonsinas. Nota de apresentação de Mário Júlio de Almeida Costa. Lisboa: Fundação Calouste Gulbenkian, 1984.

${ }^{2}$ Apesar de ser considerada a primeira compilação de leis organizadas, é importante referir que o Livro de Leis e Posturas é a primeira compilação legal. Embora rudimentar, alguns autores consideram-na o prenúncio às Ordenações Afonsinas, compilação organizada. Portanto, o primeiro livro encerra em si uma compilação desordenada de leis, fruto de uma corte itinerante, mas que correspondem a uma tentativa de sistematização do direito português.

${ }^{3}$ Importa ressalvar que a Chancelaria de D. João II consultada pertence a um projeto de transcrição, pelo que não tive acesso à sua totalidade. Desta forma, a escolha dos livros da Chancelaria foi aleatória. Este trabalho era um
} 
a dimensão da sociedade portuguesa. Por isso, qualquer conclusão que possa propor da consequente análise será sempre uma mera hipótese. Todavia, as fontes analisadas revelaramse mais do que suficientes para poder levantar algumas dúvidas.

O presente trabalho divide-se em três momentos: o primeiro constitui uma contextualização do reinado e da temática, para que se possa criar uma imagem daquilo que era a sociedade da época; a segunda consiste na análise dos títulos e dos capítulos das Ordenações Afonsinas referentes ao tema tratado, permitindo uma aproximação à aplicação da justiça; por fim, é feita a análise dos resultados de investigação.

\section{Os Reinados}

A base documental centra a sua cronologia nos reinados de D. Afonso V e D. João II. Antes de avançar é crucial caracterizar genericamente a sociedade do tempo, bem como o Reino.

O Reinado de D. Afonso V foi um dos mais longos em Portugal, tendo durado 43 anos, incluindo o período de regência. O Africano coexiste com uma grave crise económica, característica do período baixo-medieval. Todavia, as conquistas em África permitem que matize a crise que assolava o reino. Segundo Luís Miguel Duarte, deve ser considerado um reinado de continuidade dos processos que os seus antecessores iniciaram, sem que tenham existido mudanças drásticas ${ }^{4}$. Verifica-se a institucionalização de mecanismos de governo, criação de rotinas e a automatização do poder, resultados de medidas previamente tomadas, que se transformaram em rotinas. A promulgação no seu reinado das Ordenações Afonsinas cultivou a ideia de que teria sido um legislador, não tendo legislado mais que os seus antecessores. Aliás, a compilação das leis não é pensada no seu reinado, mas no de D. João I fruto das queixas que surgem nos Capítulos das Cortes. Por conseguinte o processo de compilação inicia-se através de João Mendes, sendo terminado pelo Doutor Rui Fernandes em 1446, durante a Regência. Por isso, são denominadas Afonsinas ${ }^{6}$.

projeto de publicação dessa chancelaria, coordenado pelo Prof. Eduardo Borges Nunes, da Faculdade de Letras de Lisboa, no âmbito do Centro de Damião de Góis, anexo à Torre do Tombo. Tanto quanto se sabe, ficou bastante incompleto. Restam as transcrições da totalidade de alguns livros e de parte de outros, dificilmente atingindo a terça parte daquela chancelaria. Os documentos são publicados com bons sumários, mas também com a elisão de numerosas passagens, substituídas por “(...)”. Esse material serviu perfeitamente os meus propósitos científicos, mas as suas limitações são evidentes. Neste sentido, e pelo facto de a documentação consultada não estar publicada, ao longo do artigo farei referência à Chancelaria existente no Arquino Nacional- Torre do Tombo.

${ }^{4}$ DUARTE, Luís Miguel - Justiça e Criminalidade no Portugal Medievo (1459-1481). Textos Universitários de Ciências Sociais e Humanas. Lisboa: Fundação Calouste Gulbenkian, 1999. p. 107.

${ }^{5}$ Segundo José Domingues, As Ordenações Afonsinas são uma etapa de um longo processo de compilação e representam uma reforma nas ordenações. Para maior informação sobre as Ordenações e direito consultar DOMINGUES, José - As Ordenações Afonsinas. Três séculos de Direito Medieval [1211-1512]. Sintra: Zéfiro, 2008.

${ }^{6}$ DUARTE, L. M. - Justiça e Criminalidade... p. 108. 
D. João II, Príncipe Perfeito, segundo António Almeida, ao assumir o trono em 1481 vê-se a braços com "um reino caótico, cuja população vivia miseravelmente e onde imperava a bipolarização social, com a consequente lei do mais forte a imperar." 7 . Daí um forte descontentamento das classes mais desfavorecidas com os grandes senhores, culpando-os por viverem na miséria. ${ }^{8} \mathrm{O}$ seu reinado é, ainda, marcado pela morte do filho e pelos conflitos com os Grandes do Reino.

Com a ação governativa de D. João II foi possível a reorganização do reino, o fortalecimento do papel da Coroa e a realização de reformas necessárias, focando-se inicialmente na ameaça que os grandes senhores representavam.

Começando em 1481, dedica-se a pequenas reformas na Justiça, que ganham força entre 1486 e 1488, momento em que o seu poder está mais organizado e fortalecido. As cartas de perdão por si outorgadas revelam um monarca "exigente na justiça, mas generoso no perdão..." 9 . Inseridas na sua política de justiça e de acalmia do reino, são exemplos da atribuição de uma nova oportunidade aos presumidos ou verdadeiros delinquentes.

Paralelamente, o seu reinado é um momento de transição impulsionada pela tensão entre duas forças: o tradicionalismo da Idade Média e a abertura da Idade Moderna. Inserido na segunda metade do século XV, caracteriza-se pelo Renascimento, pela fragilidade do Papado e a sua tentativa de renovação religiosa, pelo fortalecimento dos Estados com monarcas centralistas (Henrique VI de Inglaterra, Reis Católicos e Luís XI de França), e pela abertura a outros continentes através das expedições marítimas. Estas pequenas transformações criam e potenciam dinâmicas de mudança. Apesar de todos os períodos da história serem momentos de transição, parece existir de alguma forma uma sobreposição de ciclos evolutivos neste reinado criando uma zona cinzenta de ação. Há a coexistência de políticas e valores medievais, bem como a afirmação de comportamentos modernos. Motivadores de transformação, são elementos que, transportados para os contextos sociais, modificam os comportamentos e as relações sociais. Portanto, o reinado de D. João II é um marco pela forma como lida com a aristocracia, com a justiça e pelos valores que tenta implementar na sociedade. Apesar da crise, conseguiu mudá-la paulatinamente.

\footnotetext{
${ }^{7}$ ALMEIDA, António Marques De - Os descobrimentos I: O mar sem fim. In MEDINA, JOÃO (dir.) - História de Portugal. Alfragide: Ediclube, 2002. Vol. 4. p. 69. Cortes de 1482 em Par de Alvito, queixa feita pelos povos. ${ }^{8}$ ALMEIDA, A. M. de - Os Descobrimentos I... p. 69.

${ }^{9}$ ALMEIDA, A. M. de - Os Descobrimentos I... p. 69.
} 


\section{Marginalidade na Idade Média}

Entender a marginalidade pressupõe a compreensão da organização da sociedade. A sua constituição não era uniforme e nenhum indivíduo era completamente excluído, fazendo parte da "civilização" 10 . Existiam, no entanto, pessoas colocadas mais facilmente nas margens, desprezadas pela sociedade, devido à sua etnia, às suas características físicas ou ao trabalho que desempenhavam. Por exemplo, quem ocupava trabalhos relacionados com sangue, quem tinha de mexer em lixo, urina, ou coisas com mau cheiro era, de alguma forma, afastado. Mulheres, crianças e idosos eram também menos valorizados, pois não tinham capacidades físicas para o mundo medieval, competitivo pela sobrevivência.

A sociedade marginal organizava-se por grupos: o dos excluídos como criminosos, vagabundos e suicidas; o dos desprezados, grupo composto pelas mulheres, velhos, crianças, doentes, inválidos e de mesteres duvidosos; o dos marginais, loucos, pobres, mendigos e cavaleiros pobres $^{11}$; o dos carrascos, que ocupavam o fundo da pirâmide ${ }^{12}$.

A marginalidade de variados grupos era consequência do medo, talvez uma constante na vida das pessoas: o desconhecido que eventualmente pudesse pôr em causa a sobrevivência dos outros era colocado à margem. Cair na periferia social era fácil, bastando algum acidente, doença ou infortúnio da vida. ${ }^{13}$

Os temas da barregania e mancebia parecem estar associados à marginalidade medieval feminina, apesar de existir discussão sobre o tema. Se ser mulher já era um fator de subalternização e em muitos casos de desprezo, estar associada a práticas sexuais altamente condenadas na sociedade, quer pela ação da Igreja quer pela legislação laica, consistia numa sentença de exclusão. Contudo, a escolha deste caminho nem sempre era voluntária, podendo ser resultado de um azar ou infortúnio, como a violação, morte do pai ou marido, rutura dos laços familiares, emigração ou a colocação da própria família nestas práticas ${ }^{14}$. Fragilizadas e desamparadas, estas mulheres utilizam o corpo para sobreviver e se sustentarem.

Contudo, apesar de existir a marginalização de prostitutas, mancebas e barregãs, podiam ser consideradas pela sociedade como prestadoras de um serviço público. Principalmente as prostitutas, que ao longo da época medieva assistem à aceitação da sua 'profissão' como mal

\footnotetext{
${ }^{10}$ DUARTE, Luís Miguel - Marginalidade e marginais. In SOUSA, Bernardo Vasconcelos e, (coord.) - A Idade Média. In MATTOSO, José, (dir.) - "História da Vida Privada em Portugal". Vol. I, p. 174.

${ }^{11}$ ALVES, Joana Catarina Machado - As Mulheres que fazem do seu corpo sua vontade: a prostituição na Idade Média. Omni Tempore: atas dos Encontros da Primavera 2018. Porto: FLUP, 2019. p. 35.

12 DUARTE, L. M. - Marginalidade e... p. 174.

${ }^{13}$ ALVES, J. C. M. - As Mulheres que fazem do seu... p. 36.

${ }^{14}$ CARMEN PERIS, M. - La prostitución valenciana en la segunda mitad del siglo XIV. Revista D'Història Medieval. Valência. n. ${ }^{\circ} 1$ (1990) pp. 179-199.
} 
menor. Eram, de alguma forma, deviant insiders, sendo que estavam sujeitas a certas condições, apesar de serem integrantes da sociedade. ${ }^{15}$

\section{O Papel da Mulher na Sociedade}

Numa sociedade onde impera o patriarcado e a índole guerreira pode-se considerar que "o homem está no topo, a mulher na base" ${ }^{16}$. Afinal, as características mais masculinas, remetem a mulher para um lugar subalterno, já que é considerada um ser frágil, inconstante e com necessidade de proteção ${ }^{17}$. Alguns autores equacionam a hipótese de os homens medievais desconhecerem a mulher, temendo-a, bem como o seu corpo, reações, malignidade ${ }^{18}$ e poder de sedução ${ }^{19}$. Todavia, eram indispensáveis no seu mundo, sendo os veículos de propagação de linhagens. Com base nesta importância e características vão-lhes tirando o poder de iniciativa, remetendo-as para as tarefas domésticas, onde o controlo sobre elas era mais fácil.

Numa sociedade masculina, fortemente celibatária, onde se tenta reprimir a sexualidade, a mulher representa uma fonte de perturbação, uma tentação ao pecado da luxúria. A forma de combater este efeito era associar a mulher à malignidade, ao pecado, traduzindo-se na ação moralista clerical, que lhe atribui um lugar inferior, em parte baseada nas Escrituras e na figura de Eva. Estes valores acabam por se perpetuar nas mentalidades, remetendo a mulher para a subordinação. Além de se controlar e reprimir a sexualidade, associada ao pecado. Por outro lado, a partir do século XIII a sua imagem é associada ao culto da Virgem Maria, benéfico para a mulher, já que remete para a pureza e o recato. Pode, paralelamente, ter criado um maior fosso para aquelas que ‘optavam' pelo caminho do pecado. Surge, ainda, a figura de Maria Madalena, a prostituta arrependida que busca perdão. De alguma forma, a mulher passará a ser caracterizada também com base nestas personagens bíblicas. Há, portanto, uma dualidade na sua imagem, que depende em grande medida da forma como vive a sua sexualidade. Uma boa mulher deveria ser submissa e obediente, papel que irá desempenhar até bem recentemente.

Apesar de a documentação indicar que essa seria a norma vivida, tal não implica que correspondesse inteiramente à realidade. Existem contrastes entre o ideal proposto e o quotidiano. A teoria, a legislação e a realidade são variáveis distintas. Enquanto a legislação considera a

\footnotetext{
${ }^{15}$ BEIRANTE, Maria Ângela - As filhas de Eva nas cidades Portuguesas da Idade Média. In O Ar da Cidade: Ensaios de História Medieval e Moderna. Lisboa: Edições Colibri, 2008. p. 84. Sendo o termo deviant insiders de Mary Perry.

${ }^{16}$ ALVES, J. C. M. - As Mulheres que fazem do seu... p. 36.

${ }^{17}$ Neste sentido, a legislação promulgada visa protegê-la, considerando-a incapaz, em contrapartida. BEIRANTE, Maria Ângela - As filhas de Eva nas cidades... p. 75.

${ }^{18}$ Associada à imagem de Eva.

${ }^{19}$ GONÇALVES, Iria - Notas sobre a Identificação Social Feminina nos finais da Idade Média. Medievalista. Lisboa. n. ${ }^{\circ} 5$ (2008). pp. 1-19.
} 
autoridade do marido e a Igreja tenta descredibilizar a mulher, por vezes sucede o oposto. Os registos de que dispomos, apesar de indicarem uma norma, não são sinónimo da sua aplicação.

Na sociedade medieval o papel da mulher diferencia-se de acordo com o estatuto social e económico a que pertence. Todavia, independentemente do seu estatuto, dependia da figura masculina durante toda a sua vida, pois estava, quase sempre, sob proteção e jugo do pai, marido, irmão, tio, filho ou outro. No caso de não se associar a um homem a sua segurança estava em causa, conduzindo-a, muitas vezes, à marginalidade, mendicidade ou prostituição. Quando é referida na documentação, está conectada a contratos de arrendamento, normas profissionais, situações criminais ou cantigas. Porém, apesar de as fontes transparecerem um papel secundário é necessário reavaliar essas noções.

Num mundo de plurivalências, a mulher insere-se em diversos contextos, que influenciam o seu papel e estatuto. Por exemplo, as mulheres aristocráticas são um instrumento de alianças matrimoniais, tendo como principal função garantir a perpetuação de linhagens. Distanciam-se de funções públicas, sendo responsáveis pela resolução de problemas domésticos, orientação do serviço da casa pelos criados, tratamento das refeições e coordenação dos trabalhos externos e internos do lar, garantindo a subsistência deste. Paralelamente, tinham a obrigação de cuidar dos filhos, dando especial atenção às filhas, apesar de a educação ser responsabilidade do marido. ${ }^{20}$ Apenas podiam sair para eventos sociais ou a missa, fazendo-se acompanhar pelo marido ou elementos da sua confiança.

As mulheres das classes mais desfavorecidas, apesar de igualmente submetidas à autoridade do marido, eram mais livres. Com condições de vida duras são obrigadas a trabalhar, maioritariamente na agricultura, mas também na indústria têxtil, ou na regatia de alimentos nas cidades, garantindo a sobrevivência da sua família. A este trabalho junta-se a responsabilidade de cuidar dos filhos, animais, casa, de preparar produtos para a venda, ir buscar água, entre outros. Assim sendo, conviviam mais a nível social, pois as suas saídas eram constantes, apesar de o intuito ser a sobrevivência. ${ }^{21}$

Existiam, ainda, as celibatárias e viúvas, cuja vida não era fácil pois enfrentavam o diaa-dia sozinhas. ${ }^{22}$ As primeiras, sem dinheiro para ingressar num convento, dedicavam-se, por exemplo, a atividades de venda a retalho. As viúvas, por seu turno, podiam voltar para a proteção do pai ou outro homem da família, ou tentar casar uma segunda vez; geralmente,

\footnotetext{
${ }^{20}$ QUEIRÓS, Isabel Maria de Moura Ribeiro - Theudas e Mantheudas. A Criminalidade feminina no reinado de D. João II através das cartas de perdão (1481-1485). Porto: Faculdade de Letras, 1999. Dissertação de Mestrado em História Medieval. p. 18.

${ }^{21}$ QUEIRÓS, I. M. de M. R. - Theudas e Mantheudas... p. 21.

${ }^{22}$ QUEIRÓS, I. M. de M. R. - Theudas e Mantheudas... p. 22.
} 
enviuvavam cedo pois casavam com indivíduos mais velhos. Se quisessem permanecer sozinhas era essencial terem dinheiro. Algumas tentavam assumir as indústrias ou os negócios dos maridos, o que era permitido na legislação, mas difícil na prática. Porém, as mais jovens e menos abastadas procuravam emprego ou entravam em conventos como criadas ou irmãs laicas.

\section{Sexualidade e Matrimónio}

O matrimónio, inicialmente marcado pelo paganismo romano e germânico, era fundamental na sociedade medieva para a criação e selagem de alianças, principalmente para elementos da classe aristocrática. É com a Reforma Gregoriana, bem como o IV Concílio de Latrão, em 1215, que se altera a celebração e a validade do casamento. $\mathrm{O}$ enlace que era apenas validado pelos familiares, fica dependente da intervenção de um sacerdote, tornando o casamento sacramental e indissolúvel, anulável com a autorização papal. Além disso, este concílio proibiu, ainda, os casamentos até ao quarto grau de consanguinidade. Desta forma, a Igreja passa a intervir ativamente nas relações sociais e familiares, sendo o seu objetivo principal controlar os casamentos nobiliárquicos, que se dissolviam facilmente e podiam envolver um elevado grau de consanguinidade para manter a linhagem. Com esta nova realidade coexistiam as práticas matrimoniais anteriores, bem como o morar maritalmente, ou seja, o não serem casados pelos preceitos eclesiásticos. ${ }^{23}$ Com D. Afonso IV, legislador de bons costumes, passa a ser necessária a autorização dos pais ou tutores para se efetuar o casamento.

Gradualmente, o casamento por usus é substituído pelo confarreatio. O primeiro, recorrente até ao século XVI, consistia no casamento por coabitação, sem a bênção eclesiástica, mas de caráter público, pois existiam testemunhas e eram assinadas tabuinhas com os dotes, confirmando o consentimento mútuo. À medida que se implementam outros rituais e valores, o confarreatio ganha proeminência, consistindo no casamento solene com um ritual litúrgico. Ao reclamar o caráter público do matrimónio, a Igreja condena, desde o século $\mathrm{XV}$, os casamentos a "furto", associados aos cavaleiros, apesar de reconhecer a sua validade. Em última análise, cabe aos pais e tutores decidir qual o melhor casamento para os seus filhos e famílias, sendo que este tipo de envolvimento punha em causa o papel dos pais na tomada de decisão.

Paralelamente, a Igreja tenta controlar as práticas sexuais, implantando com dificuldade algumas reformas, nomeadamente o celibato. ${ }^{24}$ As suas propostas têm maior influência a partir

\footnotetext{
${ }^{23}$ PIZARRO, José Augusto de Sotto Mayor; SOUSA, Bernardo Vasconcelos e - A família - estruturas de parentesco e casamento, In História da Vida Privada, MATTOSO, José (dir.), SOUSA, Bernardo Vasconcelos (coord.). Lisboa: Círculo de Leitores, 2010. p. 131. Ver, também: MARQUES, A. H. de Oliveira - A Sociedade Medieval Portuguesa - Aspectos da vida quotidiana. 4a ed. Lisboa: Livraria Sá Da Costa Editora, 1981.

${ }^{24}$ António Resende aponta a realização de diversos sínodos de bispos portugueses com o objetivo de pôr termo às práticas sexuais de clérigos, demonstrando que há dificuldade em implementar estas reformas de cariz sexual. Adotadas depois do Século XV. ALMEIDA, A. M. de - Os Descobrimentos I...
} 
do século XV, na viragem para a Idade Moderna; até lá o discurso da Igreja não era unitário. Existem diferenças entre o coletivo e o individual, não se podendo confundir "valor ou ideias com as normas" 25 .

A partir do século XIII, a evolução da moral clerical e a sua propagação motivam a marginalização progressiva da sexualidade. Deixa de ser permitido o divórcio, que era autorizado pelos costumes municipais e tolerado pelas autoridades. Combate-se a barregania, dada a sua confusão com o casamento de facto, proíbem-se as relações pré-matrimoniais, até então usuais. Por fim, condenam-se as carícias e contactos corporais como pecados sexuais ${ }^{26}$. Com o discurso moralista, as práticas sexuais foram caracterizadas de forma depreciativa, passando a ser desvios da sociedade e tabu. Afinal, o objetivo da união sexual entre homem e mulher, era a procriação, sendo os restantes comportamentos desviantes pecado. Aliás, a prática sexual era bastante reduzida, condicionada pelo calendário cristão que definia as datas possíveis. Por exemplo, durante a Quaresma, feriados religiosos e domingos era expressamente proibida. Além disso, a homossexualidade (sodomia), prostituição, masturbação e relação 'prazerosa' eram consideradas transgressões graves, principalmente a primeira. À medida que esta narrativa se instala sociedade, os comportamentos são alterados e mais controlados pela Igreja.

Outra questão que se insere neste tema é o valor atribuído à virgindade feminina. Considerada uma espécie de 'mercadoria', era importantíssima, visto que a mulher devia manter-se 'pura' até ao casamento. Ser virgem era sinónimo de honra e pureza; quando esta era corrompida considerava-se um ataque à honra, principalmente do pai, já que a menina era sua 'propriedade'. ${ }^{27} \mathrm{O}$ valor e importância da mulher variavam de acordo com este fator. Neste sentido, surge o culto à Virgem Maria, pura, exemplo do que a mulher deveria ser. Os pais, dos mais poderosos aos mais pobres, "guardavam as filhas para honra e casamento", isto é, criavam as meninas e as jovens como um investimento, pensando em casá-las com um marido mais rico ou de mais elevado estatuto social.

Portanto, ao longo da Idade Média, graças à narrativa eclesiástica, o casamento transforma-se numa instituição e ganha um ritual sacramental, passa a ser indissolúvel. A sexualidade é controlada, o seu único objetivo é a procriação, nunca o prazer.

\footnotetext{
${ }^{25}$ MATTOSO, José - A sexualidade na Idade Média portuguesa. In Naquele Tempo - Ensaios de História Medieval. Lisboa: Círculo de Leitores e Temas e Debates, 2009. pp. 15-38. Para maior informação consulta a seguinte dissertação: CORREIA, Cristina Patrícia Costa Constantino - A sexualidade feminina na Idade Média Portuguesa - Norma e Transgressão. [Em Linha] Lisboa: FCSH Universidade Nova de Lisboa. 2016. Dissertação de Mestrado em História - Especialização em História Medieval.

${ }^{26}$ Até aí, só a efusão de sémen era considerada pecado sexual.

${ }^{27}$ Quando a filha era corrompida, muitas vezes, os pais querelavam à justiça, considerando um crime contra a sua honra.
} 


\section{Barregania - a sua historiografia}

"A barregania foi provavelmente um costume quase constante na alta Idade Média para os jovens nobres antes do casamento" 28 , afirma José Mattoso. Mas o que era de facto a barregania?

A definição desta prática é complexa: para alguns autores consistia na união marital entre homem e mulher solteiros que coabitassem, sem que fosse celebrada a solenidade matrimonial na presença de um clérigo ${ }^{29}$. Contudo, será de facto a melhor definição, face a inúmeros casos associados a clérigos e homens casados? Creio que inicialmente seria este o seu significado; porém ao longo da Idade Média o seu sentido alterou-se e, por consequência, a sua definição. Era confundida, frequentemente, com o casamento de facto e juras, e sendo uma prática condenada, é-o mais duramente quando envolve clérigos.

"A barregania permanece como uma união sexual socialmente aceite, e mesmo em alguns casos louvável." ${ }^{30}$. A transformação ocorre à medida que os valores da Igreja sobre o casamento são instaurados na sociedade. Existiram três tipos de barregania: o concubinato com homem solteiro; pecado cometido com homem casado; ou transgressão clerical. Embora na cronologia estudada a barregania e o termo barregã possuam um sentido pejorativo, nem sempre foi assim. A sua associação ao concubinato é que fomentou um teor depreciativo.

Estariam relacionados os termos barregão e barregã? Supõe-se que o termo barregão terá estado na origem da terminologia no feminino, barregã. $\mathrm{O}$ termo masculino nunca teve uma conotação negativa; pelo contrário, era sinónimo de "homem forte, vigoroso, corajoso, bom cavaleiro, na força da juventude" ${ }^{31}$. No século XV é utilizado com o significado de "amancebado", porém sem um sentido depreciativo, a não ser que seja adjetivado negativamente.

Em oposição, barregã era "a mulher livre que vive maritalmente com alguém, numa duração de tempo indeterminada"32. É vinculada ao concubinato e intitulada de "concubina", transformando-se na mulher de mau porte ou de má vida. Até à adoção do direito romano e dos preceitos doutrinais da Igreja, não era tão censurada. Aliás, a referência no livro de linhagens a várias mulheres que vivem em barregania ilustra este facto, como por exemplo D. Maria Pais Ribeiro (mulher de D. Sancho I), D. Maria Anes Batissela e D. Maria Viegas de Regalados.

\footnotetext{
${ }^{28}$ MATTOSO, J. - A sexualidade na Idade Média portuguesa. In Naquele Tempo... p. 21.

${ }^{29}$ NASCIMENTO, Denise da Silva Meneses - Barregania e perdão no reinado de D. João II. Locus: Revista de história. Juíz de Fora. Vol. 22, n. ${ }^{\circ} 1$ (2016). p. 108.

${ }^{30}$ MATTOSO, José - A Longa Persistência da barregania. In Naquele Tempo - Ensaios de História Medieval. Lisboa: Círculo de Leitores e Temas e Debates, 2009. p. 71.

${ }^{31}$ MATTOSO, José - Barregão-barregã: notas de semântica. In Naquele Tempo - Ensaios de História Medieval. Lisboa: Círculo de Leitores e Temas e Debates, 2009. p. 60.

${ }^{32}$ MATTOSO, J. - Barregão-barregã: notas de semântica. In Naquele Tempo... p. 60.
} 
Os primeiros ataques às barregãs dão-se no século XI, devido ao combate gregoriano a favor do celibato clerical, já que até então os próprios bispos podiam ter mulher, desde que não fosse viúva, repudiada ou prostituta. A adoção dos valores e preceitos doutrinais gregorianos, por parte dos monarcas, bem como do direito romano, serão impulsionadores de uma atuação civil nestes casos. Começam a ser promulgadas leis cujo objetivo é combater a barregania. Em Portugal, a primeira lei remonta ao reinado de D. Afonso $\mathrm{III}^{33}$; todavia é com D. João I que a legislação para os 'bons costumes' aumenta, sendo a barregania bastante condenada ${ }^{34}$.

Portanto, a condenação da barregania está intrinsecamente ligada com os valores matrimoniais e as práticas sexuais impostas por Roma. Ao designar-se depreciativamente "concubinato" à coabitação sexual, até então duradoura e respeitável, de forma a distinguir-se do matrimónio com efeitos jurídicos ${ }^{35}$, as mentalidades são alteradas. Os indivíduos até então considerados livres são associados à transgressão. Contudo, esta transformação é adotada mais rapidamente pelas camadas altas da sociedade, como a aristocracia, do que pelas mais baixas. Nestes casos, a adoção de um casamento litúrgico é demorada, por isso a coabitação é tão tolerada pela Igreja.

\section{Mancebia}

Segundo Sousa de Viterbo, manceba significa menina jovem ou. mulher prostituta, meretriz, rameira ${ }^{36}$. E à semelhança com o termo barregã, terá sido originária do masculino mancebo. Utilizado para se referir a jovem, homem muito moço ou rapaz, no caso feminino é usado maioritariamente para denominar amantes ou concubinas. A mulher amancebada era aquela que se ligava a alguém sem laços de casamento, como amante. Opõe-se, desta forma, à barregã que teria um relacionamento marital tolerado, mas que não consistia num casamento de facto. Além disso, não estaria ligada à vida desonesta, mas por serem jovens e criadas, poderia suscitar alguma suspeita.

Inicialmente, o significado atribuído a manceba poderia não ser o de concubina, mas o de moça e menina jovem, como no masculino. Todavia, determinados comportamentos ou acontecimentos levaram à sua associação com a prática do concubinato. Por exemplo, era recorrente meninas irem trabalhar para as grandes casas, para que pudessem sobreviver, sem grandes perspetivas de vida, pobres e desamparadas, viam como benéfica uma união com o patrão; muito desprotegidas face às investidas dele, eram corrompidas com facilidade. Talvez esta seja uma das justificações para o sentido posterior e atual. A manceba, que antes era a

\footnotetext{
${ }^{33}$ Referente à presença de Barregãs na Corte, In Ordenações Afonsinas, ob. cit., Livro Quinto, Título VIII.

${ }^{34}$ Dois títulos referentes aos clérigos e homens casados.

${ }^{35}$ MATTOSO, J. - A Longa Persistência da barregania... pp. 65-77.

${ }^{36}$ VITERBO, Fr. Joaquim de Santa Rosa de - Elucidário das palavras, termos e frases que em Portugal antigamente se usaram e que hoje regularmente se ignoram. Ed, crítica por Mário Fiúza. Porto: Livraria Civilização Editora, 1983-1984. Vol. 2. p. 74.
} 
moça, passa a ser aquela que se deita com homem casado, tornando-se sua amante. Podia ser a moça nova caída em desgraça.

Por sua vez, o termo mancebia tem dois significados: em primeiro designa a prática de ter manceba, amante, e a prostituição; em segundo, denomina o prostíbulo, casa ou bairro de prostituição. Estas duas definições demonstram a clara ligação que existe entre mancebia e prostituição. Considerada a atividade mais antiga do mundo, transforma-se de altamente marginalizada e condenada num mal menor da sociedade e, como tal, tolerada pelos poderes públicos e eclesiásticos. Considerada inicialmente imoral, passa a ser interpretada como um mal menor, visto que controlaria crimes como o adultério, concubinato, sodomia, violações e outras práticas sexuais. ${ }^{37}$ Era preferível a frequência de casas públicas e recorrer à prostituição, do que condenar a alma nos crimes em cima referidos, considerados bem piores. A sua existência controlada evitava males maiores e mantinha a ordem matrimonial. Nas cidades, a prostituição era controlada pelas autoridades civis, através da definição de locais de exercício livre, regras de conduta e definição de contribuições que tinham de ser pagas.

\section{O Perdão Régio, Justiça com Clemência}

Ao contrário do que se possa pensar, a justiça régia não consistia apenas na atribuição de penas e condenações; assentava também no perdão régio, de extrema importância e uma ferramenta que balanceava a justiça. Procurado por antigos marginais, malfeitores e criminosos, ou simples acusados, era apenas atribuído pelo monarca. A sua outorga permitia que os indivíduos 'retornassem' à sociedade sem que esta os pudesse condenar por um crime passado. Além disso, funcionava como elemento de controlo social, já que o crime estava dentro da sociedade e era impossível erradicá-lo completamente. Portanto, a utilização do perdão pelo monarca tinha como objetivo o controlo da marginalidade e dos problemas a ela associados.

De certa maneira o rei era colocado numa posição semelhante a Deus; daí só ele ter o poder de outorgar as cartas. Afinal, era o responsável pelos bons costumes, pacificador da sociedade e responsável por encaminhar os súbditos num caminho correto. Era a presença de Deus na terra, cabendo-lhe ser misericordioso. Além de que o seu perdão era sinónimo de salvação. Os indivíduos que o pediam nem sempre o faziam de livre vontade, mas pelo facto de terem sido denunciados em devassas, ou pelo medo de que eventualmente uma acusação fosse feita. O perdão não era, portanto, pedido quando o crime era cometido, em alguns casos; principalmente nos crimes sexuais, podia ser solicitado anos após o sucedido, ou seja, nem

\footnotetext{
${ }^{37}$ CARMEN PERIS, M. - La prostitución valenciana en la segunda mitad del siglo XIV. Revista D'Història Medieval. Valência. n. ${ }^{\circ} 1$ (1990) p. 181.
} 
sempre (ou até poucas vezes) era por problemas de consciência. Esse sentimento podia funcionar, quando muito, quando o agressor pedia perdão à parte, à vítima.

Para que pudessem ter acesso ao perdão régio, os indivíduos tinham de cumprir um determinado processo, composto pelas seguintes fases:

i. Redação da súplica, normalmente por um tabelião pertencente à cidade ou terra onde o crime tinha sido cometido ou onde a vítima habitava. Contava com a descrição da acusação, o crime e os pormenores que fossem significativos para a avaliação do processo (fuga da cadeia);

ii. Decisão régia, que surgia após o monarca ter acesso a todos os elementos necessários para a sua decisão. No caso de falta de informação, a Corte pedia-a;

iii. Disposições finais, que consistiam na carta de perdão, onde é explicado ao criminoso o que lhe poderia acontecer caso não respeitasse a vontade régia. ${ }^{38}$

\section{As Ordenações Afonsinas}

As Ordenações Afonsinas são uma fonte de extrema importância para a compreensão da evolução da barregania e da mancebia na legislação, visto que compilam todas as leis referentes a estes crimes. Permitem, ainda, perceber a organização da sociedade e as suas práticas. Composta por cinco livros que reúnem todas as leis do reino, para este trabalho o foco foi o Livro $\mathrm{V}$, dedicado ao direito e aos processos penais, que reúne todas as leis de cariz social referentes à marginalidade, costumes e práticas. A presença dos termos abordados é totalmente distinta, sendo a barregania a mais destacada e condenada. Vejamos qual a sua presença nas ordenações e as leis promulgadas.

Comecemos pela barregania, cuja primeira lei é publicada por D. Afonso III, proibindo as barregãs de permanecerem na corte. ${ }^{39}$ Porém, a partir do final do século XIII esta atividade passa a ser alvo de uma maior legislação/penalização e controlo. No reinado de D. João I são outorgadas mais duas leis: Das barregãs dos Clérigos $^{40}$, revista depois por D. Duarte e com um parêntesis de D. Afonso V; a Barregueiros Casados $^{41}$.

Devido a inúmeras queixas por parte do povo, D. João I condena o envolvimento de barregãs com clérigos. Esta lei surge face ao descontentamento de leigos que se aperceberam de que as mulheres que assumiam condição de barregãs de clérigos viviam melhor,

\footnotetext{
${ }^{38}$ DUARTE, L. M. - Justiça e Criminalidade no Portugal Medievo (1459-1481). pp. 34-37.

${ }^{39}$ Ordenações Afonsinas...Livro Quinto, Título VIII.

${ }^{40}$ Ordenações Afonsinas... Livro Quinto, Título XVIIII.

${ }^{41}$ Ordenações Afonsinas... Livro Quinto, Título XX.
} 
abandonando os pais e a possibilidade de casamento. Com isto, não respeitavam os votos dos clérigos, que viviam em pecado.

Através desta lei, o monarca legisla principalmente contra a mulher, porque não podia atuar contra o clérigo. Este seria castigado -se fosse- através de tribunais eclesiásticos. A barregã, quando era apanhada tinha de pagar 500 libras. Além da multa, deveria ser degredada da cidade na primeira vez, do arcebispado/bispado caso fosse apanhada uma segunda, e açoitada publicamente e degredada na terceira vez. A acusação podia ser feita por qualquer pessoa, sendo que esta receberia a terça parte do valor da multa, vertendo o restante para os Corregedores. No caso de serem acusadas por estes, um terço do valor revertia para as despesas da correição ou para as prisões.

As mulheres podiam ver-se livres destas penas se casassem, professassem numa ordem ou se tornassem freiras; contudo, face a uma reincidência arriscavam a pena de morte (que provavelmente nunca aconteceu). Mais tarde, o monarca revê a lei, e a multa aumenta para 1500 libras. Define que as barregãs só podem ser presas quando apanhadas em flagrante, e a revista à casa dos clérigos só pode ser feita com a certeza de que eles estão lá dentro. D. Duarte revê alguns pormenores das penas; quem fosse apanhada uma terceira vez seria degredada com pregão até obter mercê. Além disso, obriga a que os juízes inquiram uma vez por mês sobre esta infração nas suas cidades. D. Afonso $\mathrm{V}$ apenas faz um reparo, fruto das queixas de que os seus oficiais desrespeitam as leis e vão a casa dos clérigos e prendem indivíduos sem que esteja provado qualquer pecado. Como no caso dos clérigos de idade avançada, que precisavam de ajuda de uma mulher, na sua enfermidade, para amassar o pão e lavar a roupa (era esta a expressão utilizada no pedido ao rei de autorização para os velhos sacerdotes terem uma criada em casa sem que ela fosse acusada). A ordenação torna claro que os clérigos podem ter servidora para os ajudar em serviços legítimos, caso tenham pelo menos 60 anos e as mulheres honestas mais de 50 . Os seus oficiais só podem prender alguém com suspeita, testemunhas e se o delito estiver provado.

$\mathrm{Na}$ segunda lei dos barregueiros casados, o monarca tentou quebrar a prática de os homens deixarem bens às barregãs, em prejuízo das suas mulheres legítimas e filhos. Para isso definiu multas, cujo valor variava de acordo com a posição na sociedade e os bens que possuíssem. Decretou ainda o degredo da barregã do lugar em que mora e da correição, ou os açoites públicos. No caso de os barregueiros serem presos, só abandonam a prisão quando pagam a multa. Os valores das multas eram distribuídos da mesma forma que nas barregãs dos clérigos. Só se alteravam, caso fosse um oficial do rei a efetuar a acusação: este receberia $2 / 3$ da multa. Apesar de ambos pagarem multas, as penas corporais eram exclusivas da barregã. $\mathrm{O}$ 
valor das multas duplicava em caso de reincidência. Segue-se uma tabela com a compilação do valor das multas que os indivíduos tinham de pagar. ${ }^{42}$

Tabela 1 - Compilação dos valores das multas aplicadas aos indivíduos casados.

\begin{tabular}{|l|c|c|}
\hline \multicolumn{1}{|c|}{ Categoria/Bens } & $\begin{array}{c}\text { Multa Homem } \\
\text { Primeira vez, em } \\
\text { libras }\end{array}$ & $\begin{array}{c}\text { Multa Barregã } \\
\text { Primeira vez, em } \\
\text { libras }\end{array}$ \\
\hline Pobre a 300 libras & 25 & 12,5 \\
\hline 300 a 500 libras & 40 & 20 \\
\hline 500 a 1000 libras & 70 & 35 \\
\hline 1000 a 2 mil libras & 75 & 37,5 \\
\hline 2mil a 5mil libras & 150 & 75 \\
\hline 5 mil a 10 mil libras & 200 & 100 \\
\hline 10 mil a 15 mil libras & 300 & 150 \\
\hline 15 mil libras a 20 mil libras & 400 & 200 \\
\hline 20 mil libras & 500 & 250 \\
\hline Oficiais Reais & 500 & 250 \\
\hline Ofícios Pequenos & 200 & 100 \\
\hline Mesteres Honrados c/Tenda & 200 & 100 \\
\hline Mesteres & 150 & 75 \\
\hline
\end{tabular}

FONTE: Ordenações Afonsinas, Livro V, Título XX

Por fim, existia uma lei ${ }^{43}$ que, apesar de não referir diretamente a barregania, proibia solteiros de viverem em ajuntamento carnal, o que era considerado ilegal e pecado.

A legislação sobre a mancebia é parca, existindo apenas uma lei que se relaciona com os rufiães ${ }^{44}$. Manda esta que se a manceba tivesse rufião, ambos teriam de pagar 500 libras, que o acusador receberia. Eram, ainda, açoitados, só saindo da prisão quando esta pena fosse cumprida. No caso de o rufião ser escudeiro com traje, só a manceba era açoitada.

As ordenações ainda declaram que é legal o marido matar a mulher, se a encontrar em flagrante adultério ${ }^{45}$. Os frades não eram presos caso fossem achados com mulheres, apenas deviam ser entregues ao seu superior ${ }^{46}$. Outra peculiaridade é que não era permitido o relacionamento entre etnias; era fortemente condenado o envolvimento de cristãos com muçulmanas ou judias ${ }^{47}$, mas assustava sobretudo que mouros ou judeus se envolvessem com mulheres cristãs, devido à possibilidade de estas engravidarem de 'infiéis'.

\footnotetext{
${ }^{42}$ Por Oficiais Reais entenda-se procuradores, prelados, vogados. Os Ofícios pequenos são Tabeliães, Escrivães, outros. Por mesteres honrados entenda-se Alfaiates, Ourives, Sapateiros, Ferreiros, Candieiros.

${ }^{43}$ Ordenações Afonsinas... Livro Quinto, Título XXIIII.

${ }^{44}$ Ordenações Afonsinas... Livro Quinto, Título XXII.

${ }^{45}$ Ordenações Afonsinas... Livro Quinto, Título XVIII.

${ }^{46}$ Ordenações Afonsinas... Livro Quinto, Título XXI.

${ }^{47}$ Ordenações Afonsinas... Livro Quinto, Título XV.
} 
A consulta desta fonte motiva uma questão: a maior presença de leis de controlo da barregania. Haveria uma maior preocupação com a barregania, por ser uma prática mais corrente? Era aquela que interferia mais com as famílias legítimas? As mancebas não eram tão castigadas legalmente porque se associavam à prostituição? Eram consideradas menos perigosas para a 'ordem social'?

\section{O que nos dizem as cartas de perdão?}

Através da análise de alguns livros da Chancelaria de D. João II reuni uma amostra de 237 cartas de perdão, um número pouco significativo e pouco representativo da sociedade do tempo, bem como do total das cartas outorgadas pelo monarca. Por isso, repito que os resultados apresentados valem apenas o que vale a amostra e não refletem o quotidiano dos indivíduos. Portanto, as conclusões serão meras hipóteses e, espero, uma pequena parte da verdade.

Como já referi, 100 cartas falam de barregania e 137 de mancebia; para reunir as primeiras percorri 16 livros da Chancelaria de D. João II, enquanto para as segundas utilizando apenas três livros foi possível chegar a um valor suficiente, de forma que a análise fosse equitativa no número de casos. O que mostra, desde logo, uma desproporção na ocorrência dos delitos e motiva algumas questões.

A maior presença da mancebia indica que era a prática mais corrente e a barregania tinha decrescido? Se sim, porquê? Primeiro, pode ser o resultado da legislação contra a barregania, que acabou por afastar algumas pessoas deste crime e ganhando terreno, assim, a mancebia. Paralelamente, as mentalidades podem ter mudado, com a aceitação crescente do matrimónio proposto pela Igreja, por parte da sociedade. Estes dois fatores podem ter motivado o decréscimo desta prática, e por consequência, a necessidade de cartas de perdão. Pode indicar que o termo barregã caiu em desuso e foi associado definitivamente à meretriz, significado atribuído à manceba. Assim, as barregãs "theudas e mantheudas" passam a ser mancebas. Seguindo esta hipótese, o facto de a legislação contra a mancebia ser mais leve e menos clara, bem como a sua associação ao adultério, pode ter motivado o decréscimo da utilização do termo barregã, que era mais punido e prejudicial. Podendo existir assim uma transição em que a barregã deixa de ser aquela que partilha casa, mas a amante/prostituta. 


\section{A Barregania}

Passemos à análise das cartas referentes à barregania ${ }^{48}$, que inesperadamente para mim são outorgadas maioritariamente a homens. Estes representam $88 \%$ da amostra, 88 cartas, e é através das suas cartas que se retira informações, ainda que parcas, sobre as suas barregãs. $\mathrm{O}$ facto de apenas 12 cartas serem pedidas por mulheres desperta diversas questões.

Se a legislação condena principalmente as barregãs, e não os seus companheiros, não deveriam ser estas a pedir a maioria das cartas? Compreender quem eram estas mulheres, passa por analisar quem eram os homens. E das informações facultadas pelas cartas pode-se fazer uma pequena reconstrução dos seus relacionamentos.

Apesar de o foco serem as cartas de perdão, a amostra referente à barregania comporta variantes destas, como cartas ao carcereiro ${ }^{49}$ e não à barregã, através das quais é possível saber apenas o nome daquelas que fugiam da cadeia. A seguinte tabela demonstra a presença de cada género na documentação analisada.

Tabela 2 - Tipo de cartas presentes na análise da barregania.

\begin{tabular}{|c|c|c|c|c|c|c|c|}
\hline $\begin{array}{c}\text { Género } \\
\text { Carta }\end{array}$ & $\begin{array}{c}\text { Carta de } \\
\text { Perdão }\end{array}$ & $\begin{array}{c}\text { Carta de } \\
\text { Segurança }\end{array}$ & Ambas & $\begin{array}{c}\text { Carta } \\
\text { carcereiro }\end{array}$ & $\begin{array}{c}\text { Licença P/ } \\
\text { Servidora }\end{array}$ & $\begin{array}{c}\text { Levantar } \\
\text { Degredo }\end{array}$ & Outra \\
\hline $\mathbf{N}^{\mathbf{0}}$ & 61 & 2 & 4 & 12 & 9 & 8 & 4 \\
\hline
\end{tabular}

FONTE: Chancelaria D. João II, livros: 1, 2, 5, 6, 8, 10, 12, 13, 15, 19, 20, 22, 24, 25 e 26.

Vários homens pediam licença para ter servidora, numa sociedade em que ter em casa uma mulher, mesmo que para "amassar pão e lavar roupa" ${ }^{50}$, podia gerar uma acusação de barregueiros. Para combater esta ameaça, pedem autorização. Nos casos analisados, um é padre e os restantes homens casados, mas a respetiva mulher tinha fugido. Seria a fuga de mulheres casadas recorrente? Motivadas por promessas de amor ou de uma vida melhor? Os pedidos de levantamento de degredo visavam o regresso à sua região de origem. Por fim, as cartas de

\footnotetext{
${ }^{48}$ Como já referi a Chancelaria consultada não estava totalmente transcrita, neste sentido, os gráficos referentes à barregania baseiam-se em partes de livros. Desta forma, para facilitar a enunciação das fontes mencioná-los-ei aqui pormenorizadamente. Os livros consultados na totalidade foram os: $6,8,10,13,15,20,22$. Os livros consultados parcialmente foram o: 1 e 2 . Os livros consultados apenas pelo verso: $5,12,19,25,26$. Tendo o 25 e 26 sido consultados parcialmente. Por fim, do livro 24 foram consultados os fólios 276-375 e 695-841.

${ }^{49}$ Pediam perdão, pois eram responsáveis pelos que fugiam. As prisões medievais nada tinham que ver com a realidade moderna e atual. Localizadas em casas dos carcereiros, os criminosos eram colocados todos juntos, independentemente do crime que tivessem cometido, do seu género, idade ou perigo que pudessem representar. Teriam de permanecer nestes locais decrépitos até terem pagado a sua multa ou serem condenados, portanto muitos fugiam. Esta fuga era penalizada dependendo da sua gravidade. Por exemplo quebrar ferros era bastante grave. Por consequência, os que os deixassem fugir seriam culpabilizados e pedem perdão. Daí surgirem diversos casos na chancelaria. Afinal, a fuga era recorrente e bastante fácil.

${ }^{50}$ Chancelaria de D. João II... Livro 5, fól. 12.
} 
segurança $^{51}$ estão associadas em quatro casos a cartas de perdão. Desmontar esta amostra, a meu ver, é importante para perceber que a Chancelaria não é apenas constituída por cartas de perdão, podendo estas ter diversas variantes.

A próxima tabela demonstra o estatuto daqueles que buscam o perdão régio.

Tabela 3 - O Estatuto dos indivíduos nas cartas de perdão referentes à barregania.

\begin{tabular}{|c|c|c|c|c|c|c|c|c|}
\hline Est. & Casado & Desconhecido & Outra & Solteira & Viúva & Padre & Casada & Solteiro \\
\hline $\mathrm{N}^{\mathrm{o}}$ & 53 & 21 & 9 & 7 & 5 & 3 & 1 & 1 \\
\hline
\end{tabular}

FONTE: Chancelaria D. João II, livros: 1, 2, 5, 6, 8, 10, 12, 13, 15, 19, 20, 22, 24, 25 e 26.

Todos podiam pedir perdão, não havendo distinções de classe. Através desta tabela verifica-se que a maioria dos indivíduos que pede perdão é casada, significando que a sua barregã era a amante, e não alguém com quem mantinham uma coabitação ou união marital. Ou seja, no século XV, a barregã seria, provavelmente, a amante, não sendo obrigatória a coabitação. Em algumas cartas o estatuto não é mencionado, poderiam ser os casos de união marital? $\mathrm{Na}$ amostra apenas existe um caso de barregueiros solteiros, indivíduos que estavam juntos sem terem casado. ${ }^{52}$ Portanto, neste contexto a barregania teria caído quase completamente em desuso.

Os pedidos de perdão, de levantamento de degredo ou a licença para ter servidora, são, regra geral, aceites pelo monarca e outorgados. Afinal, era assim que ele mostrava a sua misericórdia. Porém, em alguns casos, como está previsto nas Ordenações, eram cobradas multas. Na presente amostra foram pagas 30 multas e lançados dois degredos, sendo os pedidos do seu levantamento atendidos. A tabela que se segue demonstra os valores mais cobrados, em reais. Estes tinham dois destinos: a Arca da Piedade, espécie de 'cofre' de que o monarca se fazia acompanhar, cujo montante era entregue aos mais pobres; ou o Tribunal da Relação, geralmente associado às despesas que o processo envolvia e revertia para a prisão. ${ }^{53}$

Tabela 4 - Valores das multas cobradas nas cartas de perdão referentes à barregania.

\begin{tabular}{|c|c|c|c|c|c|c|c|c|c|c|c|c|c|}
\hline $\begin{array}{c}\text { Valor } \\
\text { (reais) }\end{array}$ & $\mathbf{2 0 0}$ & $\mathbf{3 0 0}$ & $\mathbf{4 0 0}$ & $\mathbf{5 0 0}$ & $\mathbf{6 0 0}$ & $\mathbf{7 0 0}$ & $\mathbf{7 7 0}$ & $\mathbf{8 0 0}$ & $\mathbf{9 0 0}$ & $\mathbf{1 0 0 0}$ & $\mathbf{1 5 0 0}$ & $\mathbf{2 0 0 0}$ & $\mathbf{4 0 0 0}$ \\
\hline $\mathrm{N}^{\mathrm{o}}$ & 2 & 5 & 5 & 3 & 2 & 3 & 1 & 1 & 1 & 3 & 2 & 1 & 1 \\
\hline
\end{tabular}

FONTE: Chancelaria D. João II, livros: 1, 2, 5, 6, 8, 10, 12, 13, 15, 19, 20, 22, 24, 25 e 26.

\footnotetext{
${ }^{51}$ Entregues aos 'criminosos' para que pudessem procurar ajuda para escrever o seu pedido de perdão e resolver as devassas. Tinham um espaço de 15 dias para resolver a sua situação.

${ }^{52}$ Chancelaria de D. João II... Livro 2, fól. 80.

${ }^{53}$ A sua expressão é quase equitativa: 14 multas revertem para a Arca da Piedade, 11 para a Relação, e quatro casos não referem o destino.
} 
Os valores mais baixos associam-se, geralmente, à fuga das prisões, e os mais elevados à reincidência. No caso dos 1500 reais, era a quarta vez que se pedia perdão ${ }^{54}$, e no de $4000 \mathrm{o}$ homem teria sido arrançoado ${ }^{55}$.Quanto às multas de 1000 reais, num caso o indivíduo tentou matar outro, noutro o acusado tirou a virgindade a uma mulher, andou fugido e tinha ainda uma manceba, que seria a sua barregã. Por fim, o último delinquente tinha manceba, mas fugiu com ela tornando-se barregueiro casado. ${ }^{56}$

Seriam estes casos singulares, ou haveria uma elevada reincidência? A conclusão nesta amostra é de que não era recorrente a reincidência, estando ligada a seis casos apenas. Estes pagaram sempre multas, dependendo da quantidade de vezes em que foram apanhados. Dos restantes não temos qualquer informação. Significa que a população apenas cometia este crime uma vez e, depois do perdão, nunca regressava à tentação? Por outro lado, diversos casos duravam anos; não deve isto ser tido em conta? Provavelmente, o medo de voltara ser apanhado e ostracizado pelos seus pares trava a reincidência ${ }^{57}$. Ou depois de estas primeiras cartas serem outorgadas, alguns delinquentes reincidiram nos anos seguintes, sem terem sido acusados. $\mathrm{Ou}$ ainda voltaram a pedir perdão noutro reinado. Como a maioria das cartas não contém informação acerca deste aspeto é difícil construir uma ideia concreta. Por fim, existem 12 situações em que o envolvimento resultou em filhos ilegítimos. Tendo em conta o total de cartas que analisei, este resultado é pequeno. E eram normais as tentativas de legitimação destes filhos.

Quem eram as mulheres tidas como barregãs? Apesar de nas Ordenações as maiores penas se colocarem na mulher, a sua presença nas cartas de perdão é reduzida. São referidas apenas 70 mulheres, das quais só 12 pedem diretamente perdão.

Tabela 5 - Categoria das Barregãs presentes nas Cartas de Perdão

\begin{tabular}{|c|c|c|c|c|c|c|c|c|c|}
\hline Barregãs & Solteira & Desconhecida & S/Info. & Viúva & Casada & Casou & Manceba & Coabitação & Noiva \\
\hline $\mathrm{N}^{\mathrm{o}}$ & 38 & 14 & 6 & 5 & 3 & 1 & 1 & 1 & 1 \\
\hline
\end{tabular}

FONTE: Chancelaria D. João II, livros: 1, 2, 5, 6, 8, 10, 12, 13,15, 19, 20, 22, 24, 25 e 26.

A maioria era solteira, sendo mantida pelo seu barregueiro, ou seja, sustentada. Entre os casos menos numerosos encontram-se as viúvas, que talvez por ficarem desamparadas se juntavam a outros homens. Se elas tivessem possibilidades económicas, significará que se uniam a outros homens em busca de 'amor', de um relacionamento, mesmo sabendo dos seus casamentos? As

\footnotetext{
${ }^{54}$ Chancelaria de D. João II... Livro 15, fól. 402.

${ }^{55}$ Arrançoado significa queixar-se, agravar. Teria piorado a sua situação, visto que fugiu da prisão. Chancelaria de D. João II... Livro 13, fól. 201.

${ }^{56}$ Chancelaria de D. João II... Livro 12, fól. 641; Livro 13, fól. 533.; Livro 15, fól. 193.

${ }^{57}$ Caso de um casal que esteve 20 anos juntos o indivíduo era clérigo.
} 
mulheres casadas eram acusadas pelos maridos de cometerem adultério. Existe ainda um caso em que, após a acusação, a barregã casou, demonstrando que a reintegração prevista nas ordenações talvez funcionasse de facto ${ }^{58}$. Dos casos únicos destaca-se a noiva, que teria perdido a virgindade antes do casamento ${ }^{59}$.

\section{A Mancebia}

Das 137 cartas analisadas, 21 dizem respeito a homens e as restantes a mulheres, destacando-se logo como uma diferença da barregania. Portanto, a mancebia parece quase exclusivamente associada à mulher. $\mathrm{O}$ homem não pede perdão por ter manceba, ao contrário do que acontecia com a barregã. Será porque esta é considerada prostituta? Apesar de ser associada diversas vezes a amante, e o adultério não ser bem visto. Tendo em conta que os homens não têm denominação específica por causa disso, como os barregueiros, ter manceba parece não ser tão grave.

Gráfico 1 - Categorias dos crimes nas cartas de perdão associadas à Mancebia.

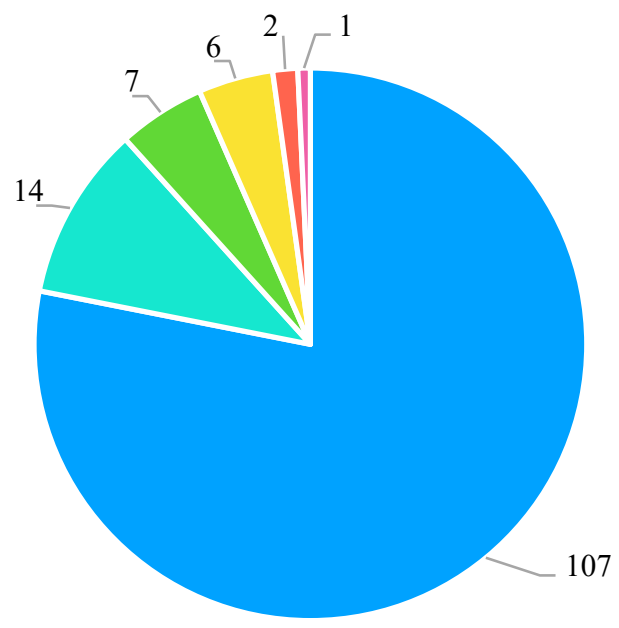

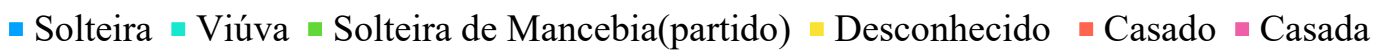
FONTE: Chancelaria D. João II, livros: 1, 2 e 5.

Através deste gráfico é visível a panóplia de crimes a que a mancebia ${ }^{60}$ pode ser associada. Apesar das semelhanças, as cartas analisadas distinguiam-nos. Mas será que faz sentido esta distinção? É pertinente diferenciar a manceba 'simples' da manceba “teúda e manteúda"? Ser "teúda e manteúda" significava ser sustentada pelo parceiro, já uma manceba poderia apenas ser um caso isolado. Nem sempre estas divisões eram feitas corretamente. Quem eram as mulheres associadas à mancebia? O próximo gráfico demonstra o estatuto que detinham na sociedade.

\footnotetext{
${ }^{58}$ Chancelaria de D. João II... Livro 22, fól. 571.

${ }^{59}$ Chancelaria de D. João II...Livro 8, fól. 39.

${ }^{60}$ Os dados aqui apresentados foram resultado da consulta de parte dos livros 1 e 2 da Chancelaria, bem como do verso do livro 5. Para facilitar a menção dos mesmo nas fontes, irei fazê-lo considerando o livro na totalidade.
} 
Gráfico 2 - Estatutos Mulheres Mancebia.

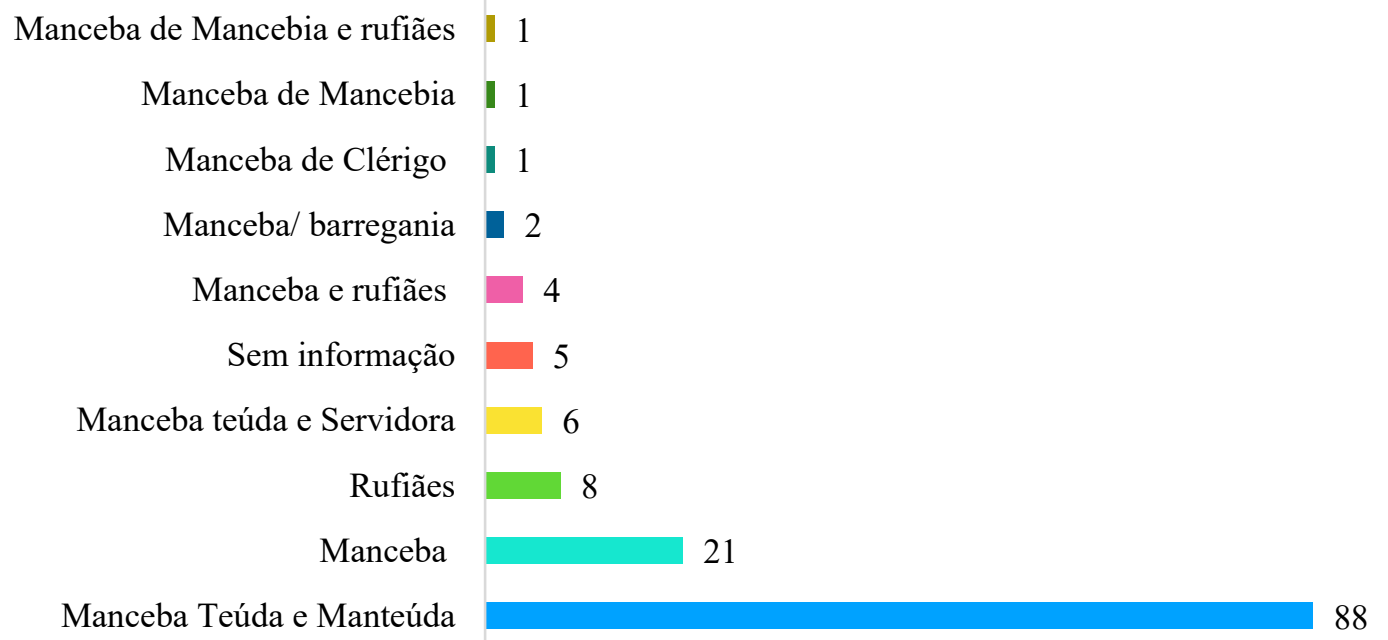

FONTE: Chancelaria D. João II, livros: 1, 2 e 5

A maioria era solteira, seguida pelas viúvas. Portanto, quem enveredava por este caminho estaria sozinha no mundo? As mulheres viúvas envolviam-se com dois tipos de homem, os casados e clérigos. O que significa isso? Que procuram uma certa estabilidade, pelo menos com os clérigos? Afinal, com eles não teriam de se comprometer maritalmente, face à dificuldade que seria casar uma segunda vez, ou manterem-se autónomas. Enquanto existe uma lei contra as barregãs dos clérigos, e não temos muitos exemplos, sucede o oposto na mancebia. Na verdade, são os clérigos a maioria dos homens a quem as mancebas aparecem associadas. Afinal, ser manceba de um clérigo era sinal de uma vida desafogada, sem se ter de dedicar ao trabalho e, quiçá, de uma história de amor. Portanto, não é estranho serem o tipo de homem mais referido.

Foquemo-nos no tipo de homem associado a mancebas, claramente dominado por clérigos.

Tabela 6 - Estatuto dos Homens Associados às mancebas nas cartas de perdão referentes à Mancebia.

\begin{tabular}{|c|c|c|c|c|c|c|c|}
\hline Estatuto & $\begin{array}{c}\text { Clero } \\
\text { Secular }\end{array}$ & $\begin{array}{c}\text { Clero } \\
\text { Regular }\end{array}$ & Casado & Desconhecido & Solteiro & Rufião & Viúvo \\
\hline $\mathbf{N}^{\mathbf{0}}$ & 51 & 37 & 23 & 10 & 10 & 5 & 1 \\
\hline
\end{tabular}

FONTE: Chancelaria D. João II, livros: 1, 2 e 5.

Não tinham a mesma punição que as barregãs caso fossem encontradas com estes indivíduos? Será que o não serem punidos pela legislação civil influencía o número elevado de clérigos? Tentaria a Igreja impedir e condenar estas situações? Em tribunais próprios e com as suas punições, ou seriam as transgressões esquecidas e toleradas? Em oposição, qual a razão de homens solteiros e casados não terem tanta presença? Prefeririam ir apenas à mancebia? Os rufiães, por sua vez, aliciavam mulheres honestas a trabalharem na 'má vida' e a sustentaremnos. Significarão estes reduzidos números que tal não acontecia com frequência no reino 
português? Estes dados podem simplesmente representar uma escolha consciente das mancebas, que encontram nos clérigos um sustento e uma vida que os homens comuns não lhes poderiam oferecer. Desta forma, juntavam-se àqueles que lhes seriam mais proveitosos. Dentro dos clérigos existem ainda ténues distinções que serão analisadas nas seguintes tabelas.

Tabela 7 - Clero Secular referido nas cartas de perdão da Mancebia.

\begin{tabular}{|c|c|c|c|c|c|c|c|c|}
\hline Tipologia & $\begin{array}{c}\text { Clérigo } \\
\text { de Missa }\end{array}$ & Clérigo & Cónego & $\begin{array}{c}\text { Clérigo e } \\
\text { Vigário }\end{array}$ & $\begin{array}{c}\text { Clérigo de } \\
\text { Missa e } \\
\text { Capelão }\end{array}$ & $\begin{array}{c}\text { Clero de } \\
\text { Missa e } \\
\text { Cónego }\end{array}$ & $\begin{array}{c}\text { Clérigo } \\
\text { Ordens } \\
\text { Sacras }\end{array}$ & Capelão \\
\hline $\mathbf{N}^{\mathbf{0}}$ & 30 & 6 & 5 & 3 & 2 & 2 & 2 & 1 \\
\hline
\end{tabular}

FONTE: Chancelaria D. João II, livros: 1, 2 e 5.

Tabela 8 - Clero Regular referido nas cartas de perdão da Mancebia.

\begin{tabular}{|c|c|c|c|c|c|c|c|c|}
\hline Tipologia & Frade & Freire & $\begin{array}{c}\text { Clérigo } \\
\text { de Missa } \\
\text { e Prior }\end{array}$ & Prior & Abade & $\begin{array}{c}\text { Clérigo } \\
\text { de Missa } \\
\text { e Abade }\end{array}$ & $\begin{array}{c}\text { Clérigo e } \\
\text { Abade }\end{array}$ & $\begin{array}{c}\text { Frade e } \\
\text { abade }\end{array}$ \\
\hline$N^{\mathbf{0}}$ & 13 & 6 & 5 & 5 & 3 & 3 & 1 & 1 \\
\hline
\end{tabular}

Justifica-se a liderança dos clérigos seculares pela sua proximidade com a população? Seriam os frades entregues ao seu superior? Conseguiriam estes homens ser respeitados mesmo assim? Existiria maior tolerância para com estes indivíduos? Afinal, nem sempre a escolha da vida clerical era autónoma, sendo 'obrigados' pela família e condições económicas a enveredar por este caminho. Assim, o respeito pelo celibato poderia ser menor.

$\mathrm{Na}$ mancebia os casos de reincidência são reduzidos, apenas 15. Significará que os indivíduos se reinserem na sociedade e se desviam definitivamente das mancebas e mancebia? Por outro lado, os filhos ilegítimos parecem ser mais: 32 casos, o dobro da barregania. Indicará isso que as mancebas permanecem mais tempo com os companheiros? Talvez sim, afinal a penalização não é tão forte. 
Gráfico 3 - Sentenças aplicadas na Mancebia.

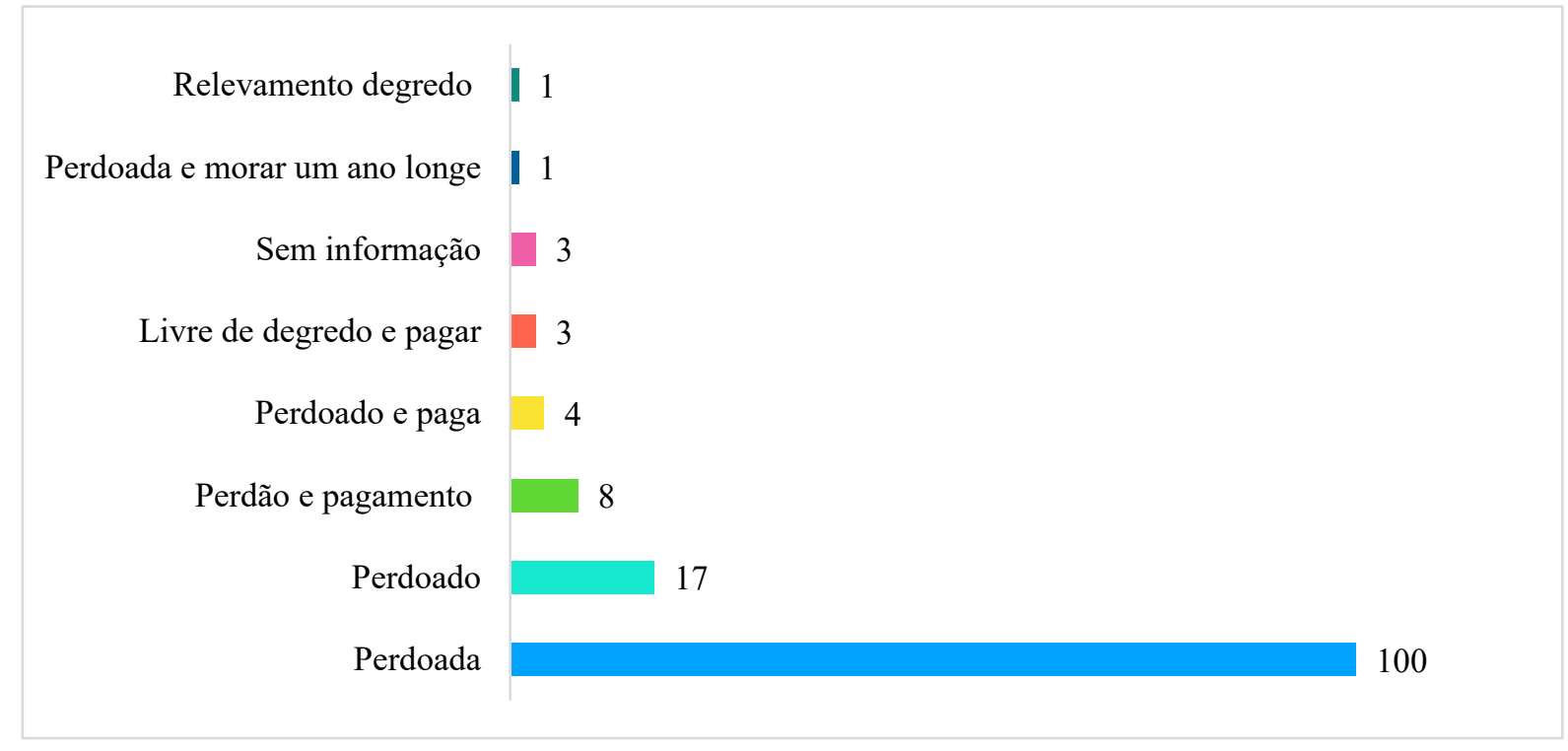

FONTE: Chancelaria D. João II, livros: 1,2 e 5.

O Gráfico 3 demonstra que as mancebas foram maioritariamente perdoadas, sem qualquer tipo de pena. Estes resultados mostram que: só 16 casos tiveram de pagar multa. A justiça parece mais branda. Porquê? Porque se olha para a manceba como a prostituta? O valor das multas é, também, menos elevado, cobrando-se geralmente 500 reais.

Tabela 9 - Valores das multas aplicadas à Mancebia.

\begin{tabular}{|c|c|c|c|c|c|c|c|c|}
\hline Valor (reais) & $\mathbf{1 0 0}$ & $\mathbf{3 0 0}$ & $\mathbf{4 0 0}$ & $\mathbf{5 0 0}$ & $\mathbf{6 0 0}$ & $\mathbf{1 0 0 0}$ & $\mathbf{1 5 0 0}$ & $\mathbf{2 0 0 0}$ \\
\hline $\mathbf{N}^{\mathbf{0}}$ & 1 & 1 & 2 & 8 & 1 & 1 & 1 & 1 \\
\hline
\end{tabular}

FONTE: Chancelaria D. João II, livros: 1, 2 e 5 .

Os valores mais elevados estão associados a crimes peculiares de reincidência. No caso da multa de 1000 reais, o indivíduo envolveu-se com uma viúva e não quis casar depois. Foi então acusado, depois de perdoado voltou a querer dormir com a querelosa, que o acusou numa devassa. ${ }^{61}$ A multa de 1500 pertence a uma viúva, que antes de casar se envolveu com um padre, voltando a fazê-lo depois de o marido falecer: "...comprado, e fingindo que per esta causa ela poderia com o dito clérigo continuar no dito pecado, sem por elo haver repreensão." ${ }^{62}$ Este excerto invoca novamente a questão; será que não era mais elevada a reincidência? Talvez fosse uma constante, não ficando registada, pois os indivíduos, não sendo acusados, não pediriam perdão.

\footnotetext{
${ }^{61}$ Chancelaria de D. João II, Livro 5, fól. 33. Carta de perdão entregue ao homem.

${ }^{62}$ Chancelaria de D. João II, Livro 5, fól. 129.
} 


\section{Conclusão}

O período medieval é uma amálgama de situações, relações, pessoas, crimes, crenças, representando a sua reconstrução um enorme desafio para o historiador. Percebemos que a sociedade medieval era rica em valores diferentes, quando não opostos, e em problemas com diversas polaridades e dinâmicas. No que diz respeito ao tema desenvolvido, a mulher não era só a esposa submissa e o ideal em que a Igreja queria que se transformasse, era uma junção das duas realidades e da sua 'liberdade' quotidiana.

Face aos resultados da investigação realizada, considero que os termos barregã e manceba são distintos, mas assiste-se a uma substituição paulatina na sociedade. O primeiro cai em desuso, fruto da vulgarização dos casamentos litúrgicos, bem como da legislação altamente penalizadora, e o segundo ganha terreno. Nota-se que a mancebia é tolerada pela lei, ao passo que a barregania não. E os pedidos de perdão da primeira associam-se a mulheres, ao passo que na barregania a maioria de pedidos é masculina. Esta realidade é visível nas ordenações, como pela leitura feita das cartas de perdão. Percebe-se, ainda, que a prática da barregania é mais associada a homens casados, enquanto a mancebia surge relacionada com clérigos.

Fica claro que ainda há caminhos por seguir nesta investigação, avaliando a profissão e as penas associadas aos indivíduos, por exemplo. Se havia pedidos de legitimação dos filhos e se estes eram aceites, que julgo serem-no sempre. Se, efetivamente, a reincidência era pouca. Se os clérigos eram condenados em tribunais próprios, questão difícil de abordar, já que não há documentação sobre isso. Há muitas investigações que podem ser feitas, permitindo reconstruir mais um pouco estas interações interpessoais e a sociedade medieva.

Concluindo, a mulher ao longo da Idade Média mantém, quando não agrava, a sua posição subalterna, destacando-se, principalmente, em crimes sexuais. Talvez seja no estatuto de manceba, principalmente de clérigo, que encontra uma maior liberdade. 


\section{Fontes}

\section{Fontes Manuscritas:}

Chancelaria de D. João II. Transcrição e edição coordenada por Eduardo Borges. 1996-2000.

Projeto no âmbito da Comissão Nacional para a Comemoração dos Descobrimentos Portugueses em parceria com o Arquivo Nacional-Torre do Tombo. Acesso facultado pelo Sr. Professor Dr. Luís Miguel Duarte, na FLUP.

\section{Fontes Impressas:}

Ordenações Afonsinas. Nota de apresentação de Mário Júlio de Almeida Costa. Lisboa: Fundação Calouste Gulbenkian, 1984. Livro V.

\section{Bibliografia}

ALMEIDA, António Marques De - Os descobrimentos I: O mar sem fim. In MEDINA, JOÃO (dir.) - História de Portugal. Alfragide: Ediclube, 2002. Vol. 4. ISBN: 84-408-0109-2.

ALVES, Joana Catarina Machado - As Mulheres que fazem do seu corpo sua vontade: a prostituição na Idade Média. Omni Tempore: atas dos Encontros da Primavera 2018. Porto: Faculdade de Letras da Universidade do Porto, 2019. pp. 33-70. Disponível em WWW: $<$ https:/ler.letras.up.pt/uploads/ficheiros/17424.pdf $>$. ISBN: 978-989-8969-08-8.

BEIRANTE, Maria Ângela - As filhas de Eva nas cidades Portuguesas da Idade Média. In $O$ Ar da Cidade: Ensaios de História Medieval e Moderna. Lisboa: Edições Colibri, 2008. ISBN: 978-972-772-696-7. pp. 65-87.

CORREIA, Cristina Patrícia Costa Constantino - A sexualidade feminina na Idade Média Portuguesa - Norma e Transgressão. Lisboa: FCSH Universidade Nova de Lisboa. 2016. Dissertação de Mestrado em História - Especialização em História Medieval. Disponível em WWW: $<$ http://hdl.handle.net/10362/21576>.

DOMINGUES, José - As Ordenações Afonsinas. Três séculos de Direito Medieval [12111512]. Sintra: Zéfiro, 2008. ISBN: 978-972-8958-66-4.

DUARTE, Luís Miguel - Justiça e Criminalidade no Portugal Medievo (1459-1481). Textos Universitários de Ciências Sociais e Humanas. Lisboa: Fundação Calouste Gulbenkian, 1999. ISBN: 972-31-0834-8.

DUARTE, Luís Miguel - Marginalidade e marginais. In SOUSA, Bernardo Vasconcelos e, (coord.) - A Idade Média. In MATTOSO, José, (dir.) - "História da Vida Privada em Portugal”. Lisboa: Temas e Debates, 2011. ISBN: 978-989-644-144-9. Vol. I, pp. 170-196. 
GONÇALVES, Iria - Notas sobre a Identificação Social Feminina nos finais da Idade Média. Medievalista. Lisboa. ISSN:1646-740X. n. ${ }^{\circ} 5$ (2008). pp. 1-19. Disponível em WWW:< https://medievalista.iem.fcsh.unl.pt/index.php/medievalista/article/view/379>. ISSN: 1646-740X.

MARQUES, A. H. de Oliveira - A Sociedade Medieval Portuguesa - Aspectos da vida quotidiana. $4^{a}$ ed. Lisboa: Livraria Sá Da Costa Editora, 1981. ISBN: 978-989-6262-41-9. MATTOSO, José - A Longa Persistência da barregania. In Naquele Tempo - Ensaios de História Medieval. Lisboa: Círculo de Leitores e Temas e Debates, 2009. ISBN: 9788986440527. pp. 65-77.

MATTOSO, José - A sexualidade na Idade Média portuguesa. In Naquele Tempo - Ensaios de História Medieval. Lisboa: Círculo de Leitores e Temas e Debates, 2009. ISBN: 9788986440527. pp. 15-38.

MATTOSO, José - Barregão-barregã: notas de semântica. In Naquele Tempo - Ensaios de História Medieval. Lisboa: Círculo de Leitores e Temas e Debates, 2009. ISBN 9788986440527. pp. 55-63

NASCIMENTO, Denise da Silva Meneses - Barregania e perdão no reinado de D. João II. Locus: Revista de história. Juíz de Fora. Vol. 22, n. ${ }^{o} 1$ (2016). pp. 187-205. Disponível em WWW: $<$ https://periodicos.ufjf.br/index.php/locus/article/view/20819>. ISSN: 2594-8296.

CARMEN PERIS, M. - La prostitución valenciana en la segunda mitad del siglo XIV. Revista D’Història Medieval. Valência. n. ${ }^{\circ} 1$ (1990) pp. 179-199. Disponível em WWW: $<$ https://roderic.uv.es/handle/10550/29602>. ISSN: 1131-7612.

PIZARRO, José Augusto de Sotto Mayor; SOUSA, Bernardo Vasconcelos e - A família estruturas de parentesco e casamento, In História da Vida Privada, MATTOSO, José (dir.), SOUSA, Bernardo Vasconcelos (coord.). Lisboa: Círculo de Leitores, 2010. ISBN 9789896441449. pp. 127-141.

QUEIRÓS, Isabel Maria de Moura Ribeiro - Theudas e Mantheudas. A Criminalidade feminina no reinado de D. João II através das cartas de perdão (1481-1485). Porto: Faculdade de Letras, 1999. Dissertação de Mestrado em História Medieval. Disponível em WWW: $<$ https://repositorio-aberto.up.pt/handle/10216/37861 $>$.

VITERBO, Fr. Joaquim de Santa Rosa de - Elucidário das palavras, termos e frases que em Portugal antigamente se usaram e que hoje regularmente se ignoram. Edição crítica por Mário Fiúza. Porto: Livraria Civilização Editora, 1983-1984. Vol. 2. 